\title{
THE RELATIONSHIP BETWEEN SOCIAL MEDIA WORD-OF-MOUTH, CONSUMER-BASED BRAND EQUITY AND CONSUMER RESPONSE AMONG AUTOMOTIVE CONSUMERS IN
}

\author{
MALAYSIA \\ Ridwan Adetunji Raji \\ Department of Media Management, School of Multimedia Technology and
}

Communication

Universiti Utara Malaysia. 06010 Sintok, Kedah Malaysia.

Email: rajiridwanadetunji@gmail.com

\begin{abstract}
The literature on Consumer-Based Brand Equity (CBBE) continues to grow enormously. Previous studies on CBBE have maintained that marketing communications play a significant role in developing $C B B E$. Furthermore, researchers have argued that social media has become a renowned and strategic platform for disseminating brand-related communication. Hence, the advent of brand-related communication on social media is as well increasing the freedom and involvement of consumers in the co-creation of brandrelated contents, thus giving rise to Social Media Word-of-Mouth. However, researchers have paid little attention to determining the role of Social Media Word-of-Mouth in developing CBBE and evoking favourable consumer behaviour. Therefore, this study sets out to examine the relationships between Social Media Word-of-Mouth, CBBE and Consumer Response. For this purpose, 290 consumers of two automotive brands were surveyed using the survey questionnaire. The data collected was analysed using both SPSS version 23 and AMOS version 23. The results revealed that Social Media Word-of-Mouth is important for enhancing CBBE and stimulating Consumer Response. Consequently, brand managers and marketers of automotive brands in Malaysia were charged to increase their engagements and investments in social media communications and encourage favourable word-ofmouths from their consumers on social media in order to improve the acceptance of their brands and increased positive consumer behaviour. This study concludes that consumer reviews, comments and posts on social media have significant implications on brands and consumer behaviour.
\end{abstract}

Keywords: Consumer-Based Brand Equity, Social Media Word-of-Mouth, Consumer Response, Automotive Brands, Malaysia 


\section{Introduction}

Studies on brand equity development and management continue to gain more attention from researchers and practitioners in different industries and business sectors (Davcik, Vinhas, Hair, \& Hair, 2015), a reason for the vastness of the body of literature on the subject. However, previous studies are not without limitations. Among the major limitations is the lack of empirical evidence on the antecedent factors and consequences of Consumer-Based Brand Equity in specific contexts and industries (Keller, 2001). As a result, the current trend among CBBE researchers is developing industry-based or context-based CBBE measurements. This new trend is especially important because CBBE functions as an important decision-making tool for customers and a success determinant for business (Keller, 2001). More so, CBBE represents consumers' perceptions and mindsets about a product and its performance, which are based on consumers' judgments of the attributes of the product. The attributes of products cannot be similar across industries because different products serve different purposes. Similarly, consumers' judgments of products' attributes are expected to differ. For example, what consumers take seriously or consider to be very important in evaluating high-involvement products like automotive products cannot be the same with low-involvement products such as soft drinks. This is why determining the factors that enhance the development of CBBE in specific industries is important (Pinar et al., 2014; Brunello, 2015).

Recently, social media has become an important platform for disseminating instant communication and anchoring online interactions among brand managers and consumers (Kaplan \& Haenlein, 2010). Bruhn et al. (2012) argued that the interactive features of social media have brought about changes in the way brand-related contents are disseminated by brand managers and how the messages are consumed by the social media users. One of the conspicuous changes is that social media users are actively involved in creating contents that influence brand equity, brand image and above all, consumer responses and behaviors. 
Consequently, brand managers, marketers and advertisers are noticeably moving away from traditional media to social media for building brand equity and developing brand relationships with consumers (Tsai \& Men, 2013). This practical shift is also noticed in the academia as many researchers have studied social media communications from a myriad of perspectives, using different scopes and methodologies (Haida \& Rahim, 2015; Dholakia et al., 2004). For instance, there have been findings on the motivations of using and participating on social media (Pokrywezynski \& Keenan, 2014), the advertising value of social media (Wellman \& Gulia, 1999), social media effect on users' perceptions (Dholakia et al., 2004), and the effect of brand followership on social media (Tsai \& Men, 2013). Similarly, different theoretical frameworks such as social network analysis (Bagozzi \& Dholakia, 2006), social influence (Bagozzi \& Dholakia, 2006), uses and gratification theory (Bagozzi \& Dholakia, 2006) and motivational theories (Bagozzi \& Dholakia, 2006) have been employed to understand the motivations of using social media, the possible impacts of using social media in relations to marketing and brand management and the influence of interaction and information obtained on social media on users' perceptions of brands (Dholakia et al., 2004; (Jusoh, Hashim, \& Adi, 2012).

These previous studies have unanimously concluded that the dialogic and participatory types of brand-related communications that are devolved on social media platforms have a significant influence on different dimensions of brand equity (Jusoh et al., 2012). Furthermore, the motivating factor for the significant shift from traditional media to social media for disseminating brand-related communications is the opportunity that brand managers get to establish a more interactive relationship between their customers and brands (Avinash Kapoor \& Chinmaya Kulshrestha, 2013). Also, the essence of social media communication is reflected through the characteristics of the contents (Avinash Kapoor \& Chinmaya Kulshrestha, 2013). However, a number of studies on social media communications have focused on the evaluation of User-Generated Contents (UGC), and researchers have not really contextualized and examined the relationship between the 
contents that are generated on social media platforms and brand equity, as well as consumer responses. Therefore, this study contextualizes social media word-of-mouth as an exemplification of UGC and examines its role in developing Consumer-Based Brand Equity (CBBE) and consumer responses.

\section{Literature Review}

\section{Definitions of CBBE}

The literature is replete with studies on the measurement of CBBE (Baalbaki \& Guzmán, 2016; Christodoulides \& Chernatony, 2010; Christodoulides, De Chernatony, Furrer, Shiu, \& Abimbola, 2006; Tuominen, 1999). These studies unanimously opined that there are two contemporary approaches to measuring $\mathrm{CBBE}$; the direct and the indirect approaches (Baalbaki \& Guzmán, 2016; Christodoulides \& Chernatony, 2010; Christodoulides et al., 2006; Tuominen, 1999). Christodoulides \& Chernatony (2010) explained that the direct approach of measuring CBBE is employed by examining the overall and direct impact of CBBE drivers on different marketing activities. Hsieh (2004) maintained that both the indirect and direct approaches are supplementary by implication. This is because the direct approach reflects how marketing communication efforts enhance brand image while the indirect approach elucidates the essence of building and managing brands through the responses and behaviors of consumers. For instance, various dimensions of CBBE such as brand awareness, brand images, associations, perceived quality, brand sustainability and so on are used to examine the implication of the brand in consumers' minds (Schivinski \& Dabrowski, 2014).

Christodoulides \& Chernatony (2010) concluded that there is no universally acceptable model for measuring CBBE. For instance, Christodoulides et al. (2006) developed five dimensions of Online Retail/Service (ORS) brand equity. According to the findings of Christodoulides et al. (2006), the dimensions of CBBE are emotional connection, online experience, responsive service nature, trust and fulfillment. A study conducted by Teck

Ming, Tze Wei, Lee, Ong, \& Su-Mae (2012) demonstrated that the dimensions of measuring 
CBBE in service shops are; tangibles, responsiveness, empathy, assurance, recovery and knowledge. More recently, Baalbaki \& Guzmán (2016) developed four dimensions of measuring CBBE based on consumer perceptions. The study concluded that perceived quality, perceived value, brand preference and sustainability all constitute a set of customer-perceived dimensions of CBBE.

Ostensibly, the literature is brimful with different types of models and methodologies for measuring CBBE. Many of the models that are available were developed conceptually while few others were empirically developed (Baalbaki \& Guzmán, 2016). Although most of the models that were empirically developed validate the Aaker's and Keller's conceptual models (Pappu, Quester, \& Cooksey, 2005; Boo et al., 2009), the body of knowledge on CBBE is yet to reach a unanimous conclusion over the measurement of CBBE (Boo et al., 2009), especially across industries and contexts.

However, in line with the empirical studies that have been done on CBBE, it can be succinctly defined as consumers' knowledge (awareness and image), mindsets, judgments and perception of the attributes, quality and performance of a brand (Verhoef, Langerak, \& Donkers, 2007; (Christodoulides \& Chernatony, 2010). The review of past studies on the measurement of CBBE revealed that, to ensure the accuracy of any model measuring CBBE, the research context, market sector, product category and pertinent industry must be taken into cognizance (Farjam \& Hongyi, 2015). In addition, measuring CBBE is important to determine the effectiveness of the elements of the marketing mix or marketing activities (Farjam \& Hongyi, 2015) and assess the traditional consequences such as consumer responses and behaviors (Ailawadi et al., 2003; Baalbaki \& Guzmán, 2016; Christodoulides \& Chernatony, 2010; Farjam \& Hongyi, 2015; Pappu et al., 2005; Boonghee Yoo \& Donthu, 2001). In the light of this, CBBE models in the context of social media and automotive brands are discussed in the following sections. 


\section{Social Media Word-of-Mouth}

Social media Word-of-Mouth (WOM) has been one of the most predominant types of marketing communications, especially since the advent of social media. This is because social media offers consumers a limitless opportunity to facilitate WOM communications (Wolny \& Mueller, 2013). Social media WOM is closely related to electronic WOM. There is no difference between the two terms as both explain a type of communication or marketing strategy which are used in encouraging consumers to help create viral messages or propagate brands on the internet (Wolny \& Mueller, 2013). Stauss (2000) added that WOM includes both negative and positive messages that are shared on social media to a throng of customers including potential, real and former customers of a product or company. Facebook, Twitter and YouTube are practical platforms for sharing consumers' evaluations, reviews and usage experiences of a product to a multitude of customers, hence social media WOM is considered a form of electronic WOM (Trusov, Bucklin, \& Pauwels, 2009; Eisingerich, Chun, Liu, Jia, \& Bell, 2014; Smith et al., 2012).

According to Doorn Van et al. (2010), the predominance of social media WOM has increased consumers' roles in the creation of brand identity and brand equity development. In addition, WOM on social media is not only influential to brand equity development, but studies have shown that it also has greater impact on consumers' purchase decisions than other marketing communications (Goldsmith \& Horowitz, 2006; Trusov, Bucklin, \& Pauwels, 2009; Eisingerich, Chun, Liu, Jia, \& Bell, 2014; (Wolny \& Mueller, 2013).

In view of the importance of social media WOM, studies have delved into different directions of social media WOM. Some studies focused on the motivations of WOM on social media (Wolny \& Mueller, 2013), types of involvements with WOM on social media

(Muntinga, Moorman, \& Smit, 2011;Christodoulides et al., 2012; Schivinski et al., 2016) and the importance of social media WOM in building brand equity (Keller, 2009). This present study tilts towards the latter approach, banking on the assumption that consumers create 
their perception of brands through the eyes of other consumers (Shi, Rui, \& Whinston, 2014).

\section{Consumer Response}

Previous studies on brand equity have asserted that there are two major phases to explaining CBBE; the attitudinal phase and the behavioral phase (Farjam \& Hongyi, 2015; Tuominen, 1999). The attitudinal aspect of CBBE explains consumers' perceptions, mindsets and of course, attitudes towards a product (Keller, 2009). Meanwhile, the behavioral aspect of CBBE explains consumers' reactions, responses and behaviors (Keller, 2009). Numerous studies have empirically demonstrated that the attitudinal aspect of brand equity significantly leads to the behavioral aspect (Mirabi, Akbariyeh, \& Tahmasebifard, 2015). The behavioral aspects are also known as consumer responses (Godey et al., 2016). However, consumer response is relevant to this present study because it mirrors the types of consumer behaviors that are aroused by the persuasiveness of marketing communication messages and consumers' knowledge, perception and attitude, hence the attitudinal aspect of CBBE (Baalbaki \& Guzmán, 2016).

A review of previous studies has shown that consumer response has been studied on a piecemeal basis (Cobb-Walgren, Ruble, \& Donthu, 1995). However, it is important now than ever to focus holistically on how social media marketing efforts and building successful brand equity influence consumers' purchase behaviors (Cobb-Walgren et al., 1995) and consumers' preference attitudes (Cobb-Walgren et al., 1995). Both brand preference and purchase intention are the most explanatory factors for consumer responses to successful brand equity and marketing communications (Cobb-Walgren et al., 1995). In view of this, both purchase intention and brand preference were adopted as the dimensions of consumer response in this present study. 


\section{Relationship between Social Media Word-of-Mouth and CBBE}

Arguably, determining the role of consumers is the underlying motivation of most previous studies that have focused on how social media affects brand equity development (Langaro et al., 2015). Most of these studies have taken different approaches to analyze the role of users of social media in building strong brand equity. Determining the effect of WOM on $\mathrm{CBBE}$ has continued to receive significant attention from researchers. In spite of that, little is known on how exactly social media WOM is affecting consumers' perception of brands. In the context of social media, majority of extant studies have focused on the effects of consumers' involvements, engagements and creation of WOM on different dimensions of CBBE (Abzari et al., 2014; Bonhommer et al., 2010; Bruhn et al., 2012; Christodoulides et al., 2012; Jalilvand \& Samiei, 2012; Karman, 2015; Karpińska-Krakowiak, 2016; Schivinski, 2011; 2015 Schivinski \& Dabrowski, 2014, 2015; Severi et al., 2014; Zailskaite-jakste \& Kuvykaite, 2012). However, far little have considered the outcome of WOM reviews on CBBE especially in the context of high involvement products like automotive brands (Jalilvand \& Samiei, 2012). In light of the above arguments, the following hypothesis is presented;

$\mathbf{H}_{1}$ : There is a significant relationship between Social Media Word-of-Mouth and ConsumerBased Brand Equity.

\section{Relationship between Social Media Word-of-Mouth and Consumer Responses}

A plethora of studies have shown that consumer behavior and responses are highly influenced by WOM (Jalilvand \& Samiei, 2012). The implication of this is that consumers consciously request for other consumers' opinions and also look out for reviews of experienced consumers before making purchase decisions of a product. Consumers do pay attention to all kinds of information ranging from price, performance of the product, functional and hedonic attributes of the product. More attention is particularly placed on this kind of review when researching high involvement products like a car (Gensler, 
Völckner, Liu-Thompkins, \& Wiertz, 2013). Social media has opened an effective window of opportunity for consumers to share their comments and reviews, deliver positive homage to brands as well as make complaints (Gensler et al., 2013). Reading such comments and reviews is expected to have a significant effect on consumer responses (Bruhn et al., 2012; Christodoulides et al., 2012; Jalilvand \& Samiei, 2012; Kim \& Ko, 2012; Zailskaite-jakste \& Kuvykaite, 2012). Therefore, this study proposed the following hypothesis;

$\mathbf{H}_{2}$ : There is a significant relationship between Social Media Word-of-Mouth and Consumer Response.

\section{Relationship between CBBE and Consumer Responses}

Theoretically, it has been established that CBBE represents consumers' mindset and perceptions (Buil et al., 2013). Ultimately, consumers' perception and mindset are not necessarily the facts or the truth about a brand. They are rather a representation of consumers' thoughts, feelings, perception, comprehension, association, image and experiences in the minds of the consumers (Zailskaite-jakste \& Kuvykaite, 2013). The nature of consumers' perception determines consumer responses (Buil, Martínez, et al., 2013b), especially in the automotive industry (Zhang, 2015). In addition, many previous studies have demonstrated that consumer perception is an antecedent of their responses (Kim \& Ko, 2012). The most significant types of consumer responses with regards to CBBE are purchase intention and brand preference (Buil, Martínez, et al., 2013b; Chang \& Liu, 2009; Chen \& Chang, 2008; Chovanová, Korshunov, \& Babčanová, 2015; Cobb-Walgren et al., 1995; Monavvarian et al., 2015; Moradi \& Zarei, 2011; Prasad et al., 2014; Tolba \& Hassan, 2009; Wu \& Jang, 2013). In a bid to determine the effect of CBBE consumer responses, previous researchers such as Schivinski, (2011), Bruno and Dabrowski, (2014), Mathews et al., (2009), Batra and Homer (2004), Khadim, Zafar, Younis, and Nadeem (2014) and Goodrich (2011) have focused on different dimensions of CBBE from different industries and contexts. However, a few studies have focused on how CBBE of automotive brands 
influence consumer response especially in terms of purchase intention and brand preference. Hence, the following hypothesis is presented;

$\mathbf{H}_{3}$ : There is a significant relationship between Consumer-Based Brand Equity and Consumer Response

\section{CONCEPTUAL FRAMEWORK}

The conceptual framework proposed in this study is presented in Figure 1. The framework proposes that there are significant relationships between Social Media Wordof-Mouth, Consumer-Based Brand Equity and Consumer Responses. The framework fundamentally predicates the implication of consumer reviews and comments on social media platforms on brand development and consumer behavior.

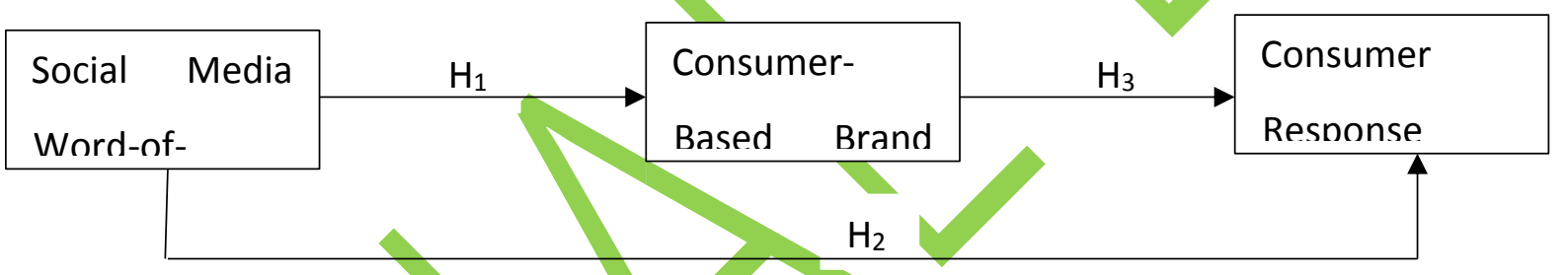

Figure 1: Conceptual Framework

\section{Methodology}

Data Collection Procedure

Data was collected in this study through survey questionnaires administered to 290 users of two automotive brands in Malaysia; PROTON and PERODUA. Both PROTON and PERODUA are the market leaders in the Malaysian automotive industry (Ghani, 2012). Furthermore, Kormin and Baharun (2016) justified that both PROTON and PERODUA have the most predominant presence on various social media platforms such as Facebook, YouTube, Instagram and Twitter in Malaysia. A cluster sampling technique was employed to select one city from each of the five geographical regions in Malaysia. As such, one major city was selected to represent each cluster/region depending on the cosmopolitan characteristics of the city. Accordingly, Penang was selected to represent the Northern 
Region, the Central Region was represented by Kuala Lumpur in this study, the Southern Region was represented by Johor Bahru and Kuantan represented the East Coast while Kuching represented the Borneo Islands. To ensure randomness in the sample selection, a random sampling selection technique was employed to determine the number of samples from each of the selected cities. The random sampling procedure recommended by Cohen, Manion and Morrison (2000) was employed in this study. The multi-stage level of item development methodology employed in this study yielded 4 items for measuring Social Media Word-of-Mouth, 6 items for Consumer Response and 29 items with four dimensions - brand awareness, functional brand image, hedonic brand image and brand sustainability for measuring CBBE of automotive brands. The scale that was used to record respondents' agreement or disagreement to the statements in the survey are based on the values of 1 strongly disagree, 2-disagee, 3-not sure, 4-agree and 5-strongly agree.

\section{Findings}

Data analysis was initiated with the use of SPSS 22 to generate the demographic information of the respondents, examine and replace missing data, and assess normality and outliers. The descriptive analyses of the respondents' information showed that majority of the respondents were users of PROTON, followed by PERODUA. It also revealed that there were more females than males among the respondents. Most importantly, majority of the respondents followed automotive brands on Facebook (88.7\%), YouTube $(30.7 \%)$, Instagram (30.7\%) and Twitter (16.2\%). The second phase of the analysis was effectuated using AMOS software version 23 for specifying both the measurement and structural models. The measurement model was specified using reflective measurements using a Confirmatory Factor Analysis (CFA). The results of the convergent validity including AVE, factor loadings and composite reliability are presented in Table 1. The result revealed that all constructs showed acceptable values greater than 0.80 , while the values of Average Variance Extracted (AVE) were greater than 0.50. Finally, the factor loadings of the items 
were acceptable and higher than 0.60. Additionally, the discriminant validity was examined using the Fornell and Larcker (1981) method. The results presented in Table 2 demonstrate that discriminant validity was established in this study. The parameter for ensuring goodness of fit for the hypothesized model including the ratio of chi-square to degree of freedom was not greater than 5.0. ( $\chi 2 / \mathrm{df}=2.189)$, RMSEA (0.047), CFI (0931), GFI (0.878), AGFI (0.861), TLI (0.926), IFI (0.911), PNFI (0.818) and SRMR (0.061) are all above the standard values as suggested by MacCallum et al. (1996), thus confirming the goodness of fit of the hypothesized model (Hair et al., 2010).

Table 1: Composite Reliability and AVE of Hypothesized Model

\begin{tabular}{|c|c|c|c|}
\hline Construct & Code & $\begin{array}{l}\text { Factor AVE } \\
\text { Loadings }\end{array}$ & $\begin{array}{l}\text { Composite } \\
\text { Reliability }\end{array}$ \\
\hline $\begin{array}{l}\text { Social Media } \\
\text { Word-of- } \\
\text { Mouth }\end{array}$ & $\begin{array}{l}\text { Both positive and negative } \\
\text { comments are posted by } \\
\text { consumers of BRAND X on social } \\
\text { media } \\
\text { After consulting consumers' } \\
\text { reviews of BRAND X on social } \\
\text { media, I am confident about } \\
\text { BRAND X } \\
\text { Consumers' reviews on social } \\
\text { media help me make decisions on } \\
\text { BRAND X } \\
\text { I often gather information about } \\
\text { BRAND X from other consumers' } \\
\text { reviews on social media }\end{array}$ & $\begin{array}{rr}.648 \quad 0.546 \\
\end{array}$ & \\
\hline
\end{tabular}




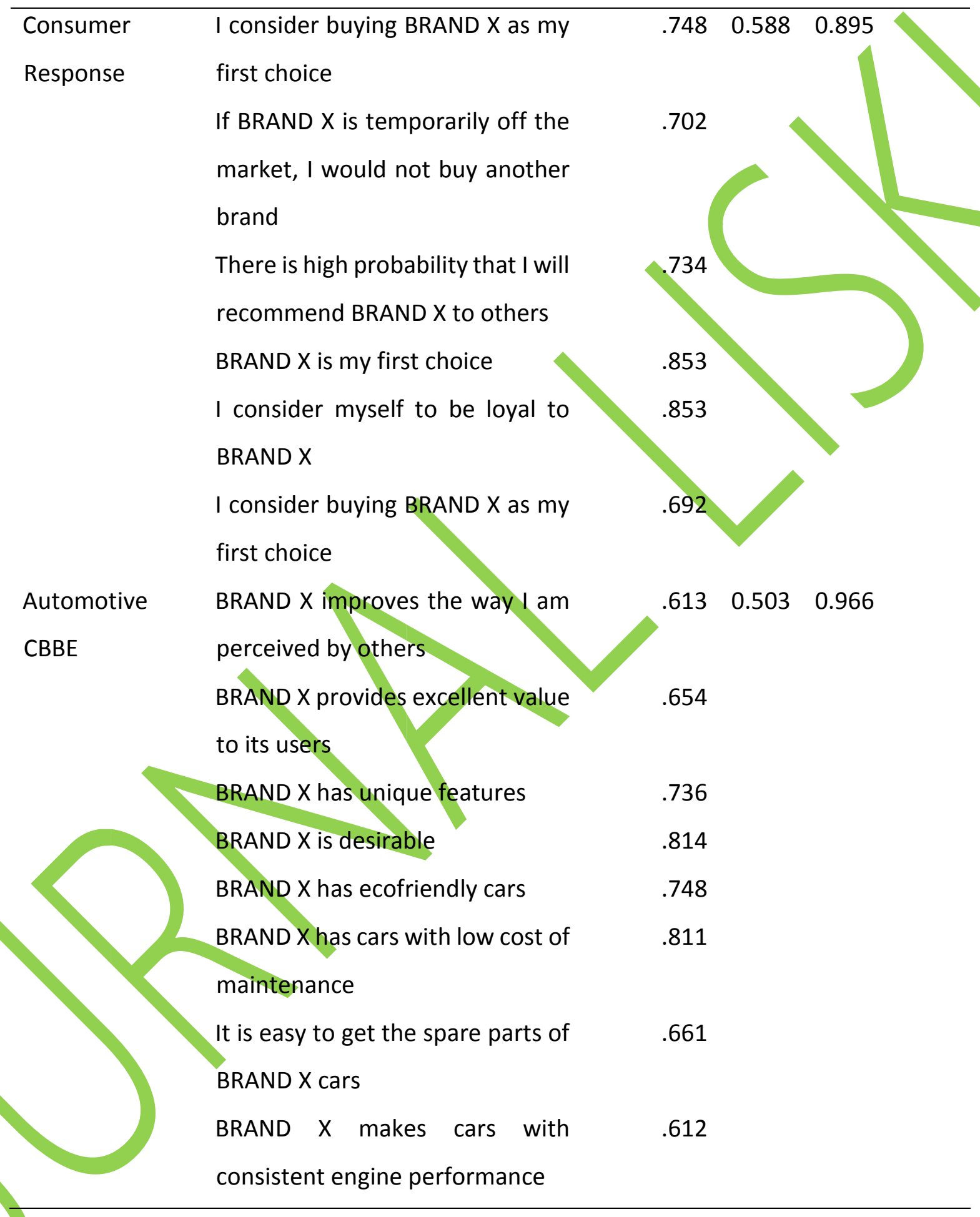


BRAND $X$ makes cars with

.676

acceptable standard of engine

quality

BRAND $X$ makes cars with good

.702

engine transmission

BRAND $X$ makes cars with good

mechanical quality

BRAND $X$ has structurally

attractive cars

BRAND $X$ has cars with very good

.650

designs

BRAND $X$ has cars with attractive

paint

BRAND $X$ has cars with good body

style

BRAND X has cars with trunk/boot

volume

BRAND $X$ has cars with trunk/boot

accessibility

BRAND $X$ has cars with interiors

that have very good

functionalities

BRAND $X$ has cars with interiors

that are very easy to use

BRAND $X$ has cars with good

driving stability 


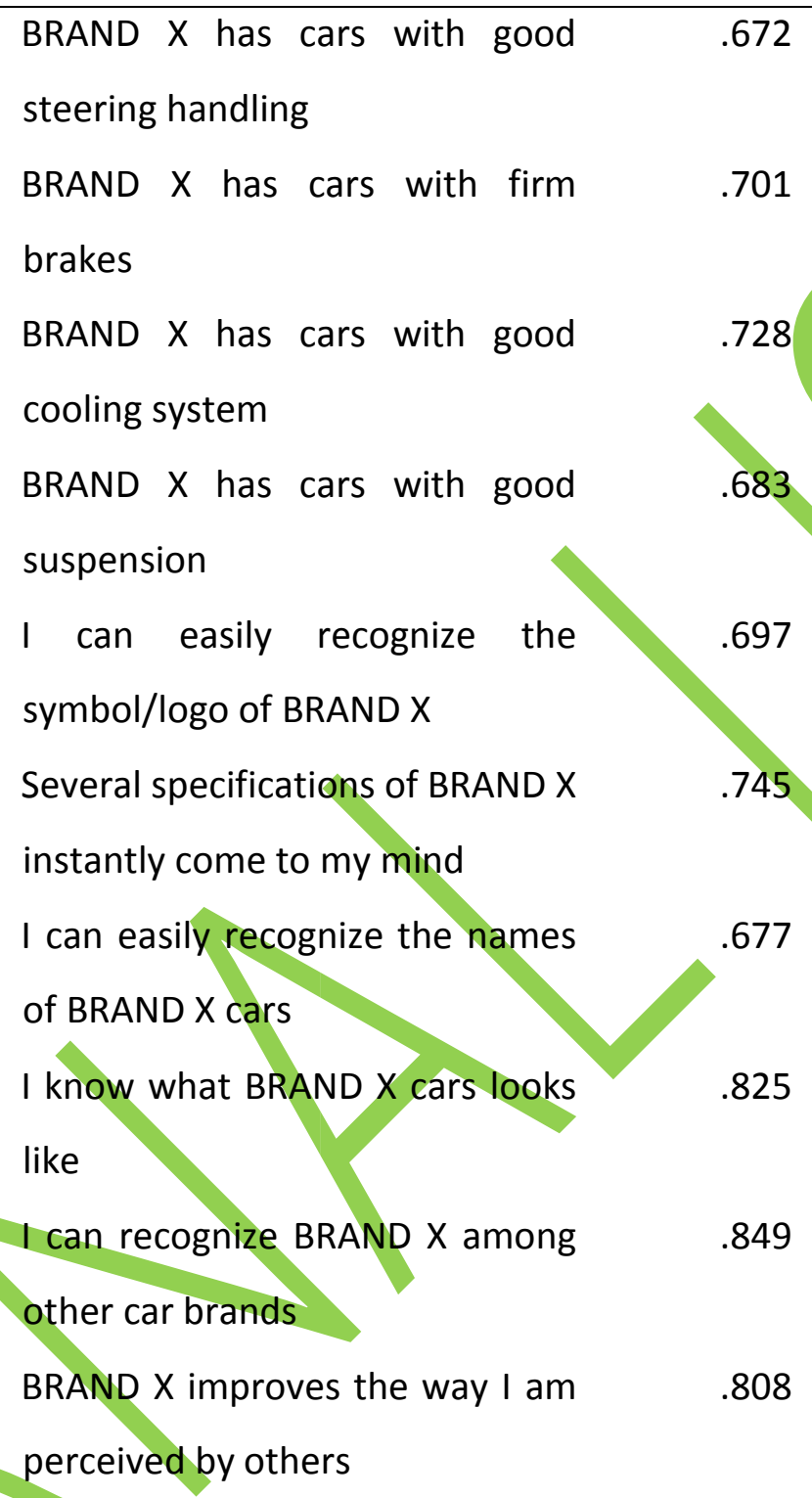

.825

I can recognize BRAND X among $\quad .849$

BRAND $X$ improves the way I am $\quad .808$

.683

.677

Table 2: Test of Discriminant Validity

Variables

\section{CBBE}

SMWOM

CR
CBBE

0.709

.446

.436
SMWOM

CR

\subsection{8}

.295 
Note: The bold numbers on the diagonal are the Square Root of AVE; off diagonal numbers are the squared correlations among constructs. Automotive Consumer-Based Brand Equity (CBBE), Social Media Word-of-Mouth (SMWOM) and Consumer Response (CR)

Furthermore, the result of the structural model presented in Table 3 demonstrated that the hypothesized framework is valid. The $R^{2}$ values for the endogenous variables of CBBE $\left(R^{2}=\right.$ 0.567) and Consumer Response $\left(R^{2}=0.534\right)$ also indicate that the model is fit and statistically acceptable. The result implied that Social Media Word-of-Mouth explains 56.7\% variation in CBBE while both Social Media Word-of-Mouth and CBBE collectively explain $53 \%$ variation in Consumer Response. Additionally, the result also evinced that there is a significant and positive relationship between Social Media Word-of-Mouth $(\beta=0.753, \mathrm{t}=$ 26.640 , Sig $=.000)$ and CBBE. This result demonstrates that Social Media Word-of-Mouth explained 75\% variation in CBBE. Social Media Word-of-Mouth also showed a significant and positive relationship with Consumer Response $(\beta=0.145, t=3.262$, Sig $=.001)$. The result revealed that, for every increase in Social Media Word-of-Mouth, there is an expected $14.5 \%$ increase in Consumer Response. Finally, the relationship between CBBE and Consumer Response is found to be significant and positive $(\beta=0.615, \mathrm{t}=13.818$, $\mathrm{Sig}=$ .000). This result highlights that, for every increase in CBBE, there is an expected $61.5 \%$ increase in Consumer Response. Based on the findings presented in Table 3, the three hypotheses formulated in this study are supported. The detailed discussion of these findings is presented in the following sections.

Table 3: Summary of the Tested Hypotheses

\begin{tabular}{|c|c|c|c|c|c|c|c|}
\hline Hypotheses & Relationships & $\begin{array}{l}\beta \\
\text { Value }\end{array}$ & Estimates & S.E. & $\begin{array}{l}\text { T- } \\
\text { value }\end{array}$ & $\begin{array}{l}\text { P- } \\
\text { Value }\end{array}$ & Remarks \\
\hline & $\begin{array}{l}\text { SWOM } \rightarrow \\
\text { CBBE }\end{array}$ & .753 & .581 & .022 & 26.640 & $* * *$ & Supported \\
\hline $\mathrm{H} 2$ & SWOM $\rightarrow$ CR & .145 & .182 & .056 & 3.262 & $* * *$ & Supported \\
\hline H3 & $\mathrm{CBBE} \rightarrow \mathrm{CR}$ & .615 & 1.000 & .072 & 13.818 & $* * *$ & Supported \\
\hline
\end{tabular}


Automotive Consumer-Based Brand Equity (CBBE), Social Media Word-of-Mouth (SMWOM) and Consumer Response (CR). ${ }^{* * *} \mathrm{P}<0.01$.

\section{Discussions}

The findings of this study demonstrate the significance of Social Media Word-ofMouth in enhancing CBBE and Consumer Response among the consumers of automotive brands in Malaysia. The result of this study imply that the comments, reviews and posts that consumers are posting on their social media platforms have significant impact on the CBBE measures and consumer behavior. Specifically, the result revealed that Social Media Word-of-Mouth is particularly important for enhancing CBBE. This is because the impact of Social Media Word-of-Mouth is found to be massive as compared to its impact on Consumer Response. The findings also revealed that CBBE is most important in evoking consumer behavior in terms of purchase intentions and brand preferences. This study provides an empirical justification to the notion that UGCs are a form of enhancing consumers' connection and engagement with brands. Furthermore, consumers' comments, experiences and personal reviews of brands that are often posted on brand social media pages have significant influence on other consumers' behaviors and perception of brands (Gensler et al., 2013) as well as their preferences in brand selection. The findings of this study are consistent with the findings of previous researchers on the impactions of brandrelated contents that are generated by consumers on social media. The study offers a number of theoretical contributions, which include the conclusion that the impact of Social Media Word-of-Mouth is more useful in enhancing and developing CBBE than its impact on Consumer Response. More so, understanding the impact of UGC and Word-of-Mouth on brand equity has a practical importance, considering the level at which consumers are adopting social media platforms to search for brand-related information lately (Adetunji, Sabrina, \& Sobhi, 2017). As such, brand managers especially the brand managers and marketers of automotive brands in Malaysia should pay more attention to engaging and relating with their consumers through social media platforms in order to improve the acceptance of their brands and to increase favorable behaviors and responses for their consumers.

This study however has certain limitations that can guide future studies. In view of the nature and features of social media, being a platform that anchors all sorts of communication with numerous content characteristics (promotion, advertisement and product information) and media types (text, video and photo), future researchers should 
consider determining the differential impacts of other social media marketing communications on CBBE and Consumer Response.

\section{Conclusions}

This paper determined the relationships between Social Media Word-of-Mouth, CBBE and Consumer Response among automotive consumers in Malaysia. Conclusively, this study revealed that there is a strong relationship between CBBE and Consumer Response. As such, the study contributes to the body of knowledge in determining the effect of social media in the realm of CBBE development and evoking favorable behaviors of consumers. The study also proffers important practical recommendations to marketing communication practitioners, brand managers and marketers of automotive brands in Malaysia to maximize the potentials of social media marketing communications in enhancing the images of their brands (Adetunji et al., 2017). Most specifically because social media's popularity continues to increase among Malaysians, marketers and brand managers should take note of the fact that Social Media Word-of-Mouth such as videos, images and comments on Facebook, YouTube, Instagram and Twitter are important for developing CBBE. 


\section{References}

Abzari, M., Ghassemi, R. A., \& Vosta, L. N. (2014). Analysing the Effect of Social Media on Brand Attitude and Purchase Intention: The Case of Iran Khodro Company. Procedia Social and Behavioral Sciences, 143, 822-826. http://doi.org/10.1016/j.sbspro.2014.07.483

Adetunji, R. R., Sabrina, M. R., \& Sobhi, I. M. (2017). User-Generated Contents in Facebook, Functional and Hedonic Brand Image and Purchase Intention. In SHS Web of Conferences (Vol. 33, p. 84). http://doi.org/10.1051/shsconf/20173300084

Ahmed, M. A., \& Zahid, Z. (2014). Role of social media marketing to enhance CRM and brand equity in terms of purchase intention. Asian Journal of Management Research, 4(3), 533-549.

Ailawadi, K., Lehmann, D., \& Neslin, S. (2003). Revenue Premium as an Outcome Measure of Brand Equity. Journal of Marketing, 67(4), 1-17. http://doi.org/10.1509/jmkg.67.4.1.18688

Alam, M. S., \& Anis, M. S. (2016). Customer purchasing decisions and brand equity : a study on multi- utility - vehicles ( MUV) in uttar pradesh india. International Journal of Economic Research, 13(3), 1267-1281.

Avinash Kapoor, \& Chinmaya Kulshrestha. (2013). A mixed-method appraoch to examining brand-consumer interactions driven by social media. Journal of Research in Interactive Marketing, 7(4), 295-311.

Baalbaki, S., \& Guzmán, F. (2016). A consumer-perceived consumer-based brand equity scale. Journal of Brand Management, 23(3), 229-251. http://doi.org/10.1057/bm.2016.11

Bagozzi, R. P., \& Dholakia, U. M. (2006). Antecedents and purchase consequences of customer participation in small group brand communities. International Journal of Research in Marketing, 23(1), 45-61. http://doi.org/10.1016/j.ijresmar.2006.01.005

Batra, R., \& Homer, P. M. (2004). The Situational Impact of Brand Image Beliefs. Journal of Consumer Psychology, 14(3), 318-330. http://doi.org/10.1207/s15327663jcp1403_12

Bonhommer, J., Christodoulides, G., \& Jevons, C. (2010). The impact of user-generated content on consumer-based brand equity. In 9th Thought Leaders International Conference on Brand Management (Vol. 61, pp. 0-16).

Boo, S., Busser, J., \& Baloglu, S. (2009). A model of customer-based brand equity and its application to multiple destinations. Tourism Management, 30(2), 219-231. http://doi.org/10.1016/j.tourman.2008.06.003

Bruhn, M., Schoenmueller, V., \& Schafer, D. B. (2012). Are social media replacing traditional media in terms of brand equity creation? Management Research Review, 35(9), 770790.

Brunello, A. (2015). Brand Equity in Premium Car Market. International Journal of Communication Research, 5(2), 128-135.

Buil, l., Martínez, E., \& Chernatony, L. De. (2013). The influence of brand equity on consumer 
responses. Journal of Consumer Marketing, 30(1), 62-74. http://doi.org/10.1108/07363761311290849

Bushelow, E. E. (2012). Facebook Pages and Benefits to Brands. The Elon Journal of Undergraduate Research in Communications, 3(December 2011), 5-20.

Chang, H. H., \& Liu, Y. M. (2009). The impact of brand equity on brand preference and purchase intentions in the service industries. The Service Industries Journal, 29(12), 1687-1706. http://doi.org/10.1080/02642060902793557

Chen, C. F., \& Chang, Y. Y. (2008). Airline brand equity, brand preference, and purchase intentions-The moderating effects of switching costs. Journal of Air Transport Management, 14(1), 40-42. http://doi.org/10.1016/j.jairtraman.2007.11.003

Chieng, F. Y. L., \& Lee, G. C. (2011). Customer-Based Brand Equity: a Literature Review. Journal of Arts Science \& Commerce, II(January 2011), 33-42.

Chovanová, H. H., Korshunov, A. I., \& Babčanová, D. (2015). Impact of Brand on Consumer Behavior. Procedia Economics and Finance, 34(15), 615-621. http://doi.org/10.1016/S2212-5671(15)01676-7

Christodoulides, G., \& Chernatony, L. (2010). Consumer Based Brand Equity Conceptualization \& Measurement: A Literature Review. International Journal of Market Research, 52(July), 44-53.

Christodoulides, G., De Chernatony, L., Furrer, O., Shiu, E., \& Abimbola, T. (2006). Conceptualising and Measuring the Equity of Online Brands. Journal of Marketing Management, 22(7-8), 799-825. http://doi.org/10.1362/026725706778612149

Christodoulides, G., Jevons, C., \& Bonhomme, J. (2012). Memo to marketers : Quantitative evidence for change. Journal of Advertising Research, 52(March), 53-65. http://doi.org/10.2501/JAR-52-1-053-064

Cobb-Walgren, C. J., Ruble, C. a., \& Donthu, N. (1995). Brand Equity, Brand Preference, and Purchase Intent. Journal of Advertising, 24(3), 25-40. http://doi.org/10.1080/00913367.1995.10673481

Cohen, L., Manion, L., \& Morrison, K. R. F. L. (2000). Research methods in Education.

CUi, W. (2011). CREATING CONSUMER-BASED BRAND EQUITY IN THE CHINESE SPORTS SHOES MARKET: Measurement, challenges and opportunities. International Marketing, (September).

Davcik, N. S., Vinhas, R., Hair, J. F., \& Hair, J. F. (2015). Towards a unified theory of brand equity: conceptualizations, taxonomy and avenues for future research. Journal of Product \& Brand Management, 24(1), 3-17. http://doi.org/10.1108/JPBM-06-20140639

Dholakia, U. M., Bagozzi, R. P., \& Pearo, L. K. (2004). A social influence model of consumer participation in network- and small-group-based virtual communities. International Journal of Research in Marketing, 21(3), 241-263. http://doi.org/10.1016/j.ijresmar.2003.12.004

Doorn van, J., Lemon, K. N., Mittal, V., Nass, S., Pick, D., Pirner, P., \& Verhoef, P. C. (2010). Customer Engagement Behavior: Theoretical Foundations and Research Directions. 
Journal of Service Research, 13(3), 253-266. http://doi.org/10.1177/1094670510375599

Eisingerich, A. B., Chun, H. H., Liu, Y., Jia, H. M., \& Bell, S. J. (2014). Why recommend a brand face-to-face but not on Facebook? How word-of-mouth on online social sites differs from traditional word-of-mouth. Journal of Consumer Psychology, 25(1), 120-128. http://doi.org/10.1016/j.jcps.2014.05.004

Farjam, S., \& Hongyi, X. (2015). Reviewing the Concept of Brand Equity and Evaluating Consumer- Based Brand Equity (CBBE) Models. ISSN International Journal of Management Science And Business Administration International Journal of Management Science and Business Administration, 1(8), 1849-5419.

Gensler, S., Völckner, F., Liu-Thompkins, Y., \& Wiertz, C. (2013). Managing brands in the social media environment. Journal of Interactive Marketing, 27(4), 242-256. http://doi.org/10.1016/j.intmar.2013.09.004

Ghani, N. H. A. (2012). Relationship marketing in branding: The automobile authorised independent dealers in Malaysia. International Journal of Business and Social Science, 3(5), 144-154.

Godey, B., Manthiou, A., Pederzoli, D., Rokka, J., Aiello, G., Donvito, R., \& Singh, R. (2016). Social media marketing efforts of luxury brands: Influence on brand equity and consumer behavior. Journal of Business Research, $x \mathrm{xx}, \mathrm{xxx}-\mathrm{xxx}$. http://doi.org/10.1016/j.jbusres.2016.04.181

Goldsmith, R. R. E., \& Horowitz, D. (2006). Measuring Motivations for Online Opinion Seeking. Marketing Science, 23(4), 545-560. http://doi.org/10.1080/15252019.2006.10722114

Goodrich, K. (2011). Anarchy of effects? Exploring attention to online advertising and multiple outcomes. Psychology \& Marketing, 28(4), 417-440. http://doi.org/10.1002/mar

Haida, A., \& Rahim, H. L. (2015). Social Media Advertising Value : A Study on Consumer's Perception. International Academic Research Journal, 1(1), 1-8.

Hautz, J., Füller, J., Hutter, K., \& Thürridl, C. (2014). Let users generate your video ads? The impact of video source and quality on consumers' perceptions and intended behaviors. Journal of Interactive Marketing, 28(1), 1-15. http://doi.org/10.1016/j.intmar.2013.06.003

Hennig-Thurau, T., Malthouse, E., Friege, C., Gensler, S., Lobschat, L., Rangaswamy, A., \& Skiera, B. (2010). The Impact of New Media on Customer Relationships. Journal of Service Research, 13(3), 311-330. http://doi.org/10.1177/1094670510375460

Hsieh, M.-H. (2004). Measuring Global Brand Equity Using Cross-National Survey Data. Journal of International Marketing, 12(2), 28-57. http://doi.org/10.1509/jimk.12.2.28.32897

Jalilvand, M. R., \& Samiei, N. (2012). The effect of electronic word of mouth on brand image and purchase intention. Marketing Intelligence \& Planning, 32(4), 413-435. http://doi.org/10.1108/02634501011078138 
Jusoh, N. A. Q. B., Hashim, F. B., \& Adi, M. N. B. M. (2012). Investigating Online Social Website Portals as Marketing Communication Medium of Malaysia Local Cosmetic SMEs. Proceedings International Conference of Technology Management, Business and Entrepreneurship 20122, 2012, 730-743. Retrieved from https://www.academia.edu/2527035/Investigating_online_social_websites_portal_a s_marketing_communication_medium_of_Malaysia_local_cosmetic_SMES?login=co de610@gmail.com\&email_was_taken=true

Kaplan, A. M., \& Haenlein, M. (2010). Users of the world, unite! The challenges and opportunities of Social Media. Business Horizons, 53(1), 59-68. http://doi.org/10.1016/j.bushor.2009.09.003

Karman, M. A. (2015). The Impact of Social Media Marketing on Brand Equity toward the Purchase Intention of Starbucks Indonesia, 3(2), 77-88.

Karpińska-Krakowiak, M. (2016). The Effects of Social Networking Sites on Consumer-Brand Relationships. Journal of Computer Information Systems, 56(3), 204-210. http://doi.org/10.1080/08874417.2016.1153894

Keller, K. L. (1993). Conceptualizing, measuring, and managing customer-based brand equity. Journal of Marketing, 57(1), 1. http://doi.org/10.2307/1252054

Keller, K. L. (2001). Building Customer-Based Brand Equity : A Blueprint for Creating Strong Brands Building Customer-Based Brand Equity : A Blueprint for Creating Strong Brands. Journal of Marketing Communications, 15(2-3), 139-155. http://doi.org/10.1080/13527260902757530

Keller, K. L. (2009). Building strong brands in a modern marketing communications environment. Journal of Marketing Communications. http://doi.org/10.1080/13527260902757530

Khadim, R. A., Zafar, B., Younis, M., \& Nadeem, M. A. (2014). Social Media Communication and Consumer Brand Perceptions. International Journal of Social Sciences and Management Studies, 1(1), 12-20.

Kim, A. J., \& Ko, E. (2012). Do social media marketing activities enhance customer equity? An empirical study of luxury fashion brand. Journal of Business Research, 65(10), 14801486. http://doi.org/10.1016/j.jbusres.2011.10.014

Kormin, K., \& Baharun, R. (2016). Social media and relationship marketing strategies of malaysian car brands. Indian Journal of Science and Technology, 9(46). http://doi.org/10.17485/ijst/2016/v9i46/107138

Langaro, D., Rita, P., \& de Fátima Salgueiro, M. (2015). Do social networking sites contribute for building brands? Evaluating the impact of users' participation on brand awareness and brand attitude. Journal of Marketing Communications, (July 2015), 1-23. http://doi.org/10.1080/13527266.2015.1036100

Li, Y., \& Mousseaux, S. (2013). Luxury fashion brands on social media : a study of young consumers ' perception. TEXTILHOGSKOLAN HOGSKOLAN I BORAS.

Lipsman, A., Mudd, G., Rich, M., \& Bruich, S. (2012). The power of "like": How brands reach (and influence) fans through social-media marketing. Journal of Advertising Research, 
52(1), 40-52. http://doi.org/10.2501/JAR-52-1-040-052

Liu, Y. (2012). Country of Origin and Customer-based brand equity: A quantitative study on Chinese cars going global. Aalto University School of Economics. Retrieved from https://aaltodoc.aalto.fi/handle/123456789/3541

Mathews, C., Ambroise, L., \& Brignier, J.-M. (2009). Hedonic and symbolic consumption perceived values: opportunities for innovators and designers in the fields of brand and product design. Proceedings of the 9th EURAM (European Academy of Management) Conference, 32p. Retrieved from http://halshs.archives-ouvertes.fr/halshs-00654731

Mirabi, V., Akbariyeh, H., \& Tahmasebifard, H. (2015). A Study of Factors Affecting on Customers Purchase Intention Case Study : the Agencies of Bono Brand Tile in Tehran. Journal of Multidisciplinary Engineering Science and Technology (JMEST), 2(1), 267273. http://doi.org/10.1017/CBO9781107415324.004

Monavvarian, A., Asgari, N., \& Hoseinabadi, A. R. (2015). Studying the Effects of Brand Equity on the Consumers Responses in the Service Markets. International Journal of Economic, Commerce and Management, United Kingdom, 3(3), 1-18.

Moradi, H., \& Zarei, A. (2011). The Impact of Brand Equity on Purchase Intention and Brand Preference-the Moderating Effects of Country of Origin Image. Australian Journal of Basic and Applied Sciences, 5(3), 539-545. Retrieved from file://C:/Users/Arjuna/Desktop/New folder/Purchase Intention/2011 Hadi Moradi.pdf

Muntinga, D. G., Moorman, M., \& Smit, E. G. (2011). Introducing COBRAs: Exploring motivations for Brand-Related social media use. International Journal of Advertising, 30(1), 13-46. http://doi.org/IJA-30-1-013-046

Muntinga, D. G., Moorman, M., \& Smit, E. G. (2011). Introducing COBRAs: Exploring motivations for Brand-Related social media use. International Journal of Advertising, 30(1), 13-46. http://doi.org/10.2501/IJA-30-1-013-046

Netemeyer, R. G., Krishnan, B., Pullig, C., Wang, G., Yagci, M., Dean, D., ... Wirth, F. (2004). Developing and validating measures of facets of customer-based brand equity. Journal of Business Research, 57(2), 209-224. http://doi.org/10.1016/S0148-2963(01)00303-4

Pappu, R., Quester, P. G., \& Cooksey, R. W. (2005). Consumer-based brand equity: improving the measurement - empirical evidence. Journal of Product \& Brand Management, 14(3), 143-154. http://doi.org/10.1108/10610420510601012

Pinar, M., Trapp, P., Girard, T., \& Boyt, T. E. (2014). University brand equity: an empirical investigation of its dimensions. International Journal of Educational Management, 28(6), 616-634.

Pokrywezynski, J., \& Keenan, K. (2014). The Role of Country of Origin in Brand Following on Sociał Media Among U.S . Consumers.

Prasad, S., Totala, N. K., Gupta, I. C., Development, H. R., Nagar, V., Extension, U. N., ... Marg, R. N. T. (2014). Social Media and Customer Purchase Decision. American International Journal of Research in Humanities, Arts and Social Sciences, 166-171.

Schivinski, B. (2011). Effects of social media communication on brand equity and brand 
purchase intention. PhD Interdisciplinary Journal, 157-162. Retrieved from http://sdpg.pg.gda.pl/pij/files/2013/09/02_2013_25-schivinski.pdf

Schivinski, B., Christodoulides, G., \& Dabrowski, D. (2016). Measuring Consumers Engagement With Brand-Related Social-Media Content: Development and Validation of a Scale That Identifies Levels of Social-Media Engagement With Brands. Journal of Advertising Research, (March), 1-18. http://doi.org/10.2501/JAR-2016-000

Schivinski, B., \& Dabrowski, D. (2014). The effect of social media communication on consumer perceptions of brands. Journal of Marketing Communications, 0(12), 1-26. http://doi.org/10.1080/13527266.2013.871323

Schivinski, B., \& Dabrowski, D. (2015). The impact of brand communication on brand equity through Facebook. Journal of Research in Interactive Marketing, 9(1), 31-53.

Schivinski, B., Łukasik, P., \& Dabrowski, D. (2015). User-generated images and its impact on consumer-based brand equity and on purchase intention. Logistyka, 52(2), 1054-1061.

Severi, E., Ling, K. C., \& Nasermoadeli, A. (2014). The Impacts of Electronic Word of Mouth on Brand Equity in the Context of Social Media. International Journal of Business and Management, 9(8), 84-96. http://doi.org/10.5539/ijbm.v9n8p84

Shi, Z., Rui, H., \& Whinston, A. (2014). Content sharing in a social broadcasting environment: evidence from twitter. Mis Quarterly, 38(1), 123-142. http://doi.org/10.2139/ssrn.2341243

Smith, A. N., Fischer, E., \& Yongjian, C. (2012). How Does Brand-related User-generated Content Differ across YouTube, Facebook, and Twitter? Journal of Interactive Marketing, 26(2), 102-113. http://doi.org/10.1016/j.intmar.2012.01.002

Spears, N., \& Singh, S. N. (2004). Measuring Attitude toward the Brand and Purchase Intentions. Journal of Current Issues \& Research in Advertising, 26(2), 53-66. http://doi.org/10.1080/10641734.2004.10505164

Stauss, B. (2000). Using New Media for Customer Interaction: A Challenge for Relationship Marketing. Relationship Marketing. http://doi.org/10.1017/CBO9781107415324.004

Teck Ming, T., Tze Wei, L., Lee, W. S. S., Ong, M. B. F., \& Su-Mae, T. (2012). Consumer-based Brand Equity in the Service Shop. International Journal of Marketing Studies, 4(4), 6077. http://doi.org/10.5539/ijms.v4n4p60

Tolba, A. H., \& Hassan, S. S. (2009). Linking customer-based brand equity with brand market performance: a managerial approach. Journal of Product \& Brand Management, 18(5), 356-366. http://doi.org/10.1108/10610420910981837

Trusov, M., Bucklin, R. E., \& Pauwels, K. (2009). Effects of Word-of-Mouth Versus Traditional Marketing: Findings from an Internet Social Networking Site. Journal of Marketing, 73(5), 90-102. http://doi.org/10.1509/jmkg.73.5.90

Tsai, W.-H. S., \& Men, L. R. (2013). Motivations and Antecedents of Consumer Engagement With Brand Pages on Social Networking Sites. Journal of Interactive Advertising, 13(2), 76-87. http://doi.org/10.1080/15252019.2013.826549

Tuominen, P. (1999). Managing Brand Equity. LTA, 1, 65-100. http://doi.org/10.2307/1252048 
Verhoef, P. C., Langerak, F., \& Donkers, B. (2007). Understanding brand and dealer retention in the new car market: The moderating role of brand tier. Journal of Retailing, 83(1), 97-113. http://doi.org/10.1016/j.jretai.2006.10.007

Wellman, B., \& Gulia, M. (1999). Virtual communities as communities. Communities in Cyberspace, 167-193. http://doi.org/10.2307/2655574

Wolny, J., \& Mueller, C. (2013). Analysis of fashion consumers' motives to engage in electronic word of mouth communication through social media platforms. Journal of Marketing Management, 29(5-6), 562-583. http://doi.org/10.1080/0267257X.2013.778324

Wu, S.-I., \& Jang, J.-Y. (2013). The impact of ISO certification on consumers' purchase intention. Total Quality Management \& Business Excellence, 25(3-4), 412-426. http://doi.org/10.1080/14783363.2013.776770

Yoo, B., \& Donthu, N. (2001). Developing and validating a multidimensional consumerbased brand equity scale. Journal of Business Research, 52(1), 1-14. http://doi.org/10.1016/S0148-2963(99)00098-3

Zailskaite-jakste, L., \& Kuvykaite, R. (2012). Consumer Engagement in Social Media by Building the Brand. In Electronic International Interdisciplinary Conference (pp. 194202).

Zhang, Y. (2015). The Impact of Brand Image on Consumer Behavior : A Literature Review. Open Journal of Business and Management, 3(January), 58-62. http://doi.org/10.4236/ojbm.2015.31006 